\title{
Relationships Between Lipophilicity and Root Uptake and Translocation of Non-ionised Chemicals by Barley ${ }^{a}$
}

\author{
Geoffrey G. Briggs, Richard H. Bromilow and Avis A. Evans \\ Rothamsted Experimental Station, Harpenden, Herts, ALS $2 J Q$ \\ (Manuscript received 6 January 1982)
}

\begin{abstract}
The uptake by roots from solution, and subsequent translocation to shoots in barley, of two series of non-ionised chemicals, $O$-methylcarbamoyloximes and substituted phenylureas, were measured. Uptake of the chemicals by roots was greater the more lipophilic the chemical, and fell to a lower limiting value for polar chemicals. Translocation to the shoots was a passive process, and was most efficient for compounds of intermediate polarity. Both processes had reached equilibrium within $24 \mathrm{~h}$ of treatment. The reported behaviour of many pesticides in various plant species agrees with the derived relationships, but the detailed mechanisms of these processes are unknown.
\end{abstract}

\section{Introduction}

Relationships between the physical properties of organic chemicals and their translocation in plants following uptake by roots have been discussed by Crowdy, ${ }^{1}$ Shone and Wood, ${ }^{2,3}$ Briggs et $a l^{4}$ and Leroux et al. ${ }^{5}$

Uptake of a chemical into roots is most conveniently described by its Root Concentration Factor (RCF) defined by Shone and Wood ${ }^{6}$ as:

$$
\mathrm{RCF}=(\text { Concentration in roots }) /(\text { Concentration in external solution })
$$

The RCF is generally independent of concentration for dilute solutions. ${ }^{5}$

The efficiency of translocation of a chemical to shoots from root uptake is described by its Transpiration Stream Concentration Factor ${ }^{6}$ (TSCF) defined by:

$$
\mathrm{TSCF}=(\text { Concentration in transpiration stream }) /(\text { Concentration in external solution })
$$

The concentration in the transpiration stream is usually assessed indirectly from the mass of chemical accumulated in the shoots for a known volume of water transpired, and the TSCF thus estimated is independent of time if the chemical is stable in the plant. ${ }^{6}$ The TSCF has been found to be independent of concentration in the external solution and has a maximum value of 1.0 for passive uptake. ${ }^{6}$

Crowdy ${ }^{1}$ suggested that there is an optimum lipid/water distribution for translocation, more polar or more lipophilic compounds being less well translocated. This paper describes measurements of the uptake by roots, and subsequent translocation to the shoots of barley plants grown in water culture, of two series of ${ }^{14} \mathrm{C}$-labelled compounds spanning a wide range of lipophilicity, as measured by their octan-l-ol/water partition coefficients. The $O$-methylcarbamoyloximes were systemic insecticides, and the substituted phenylureas were inactive analogues of 1,1-dimethyl-3-phenylurea herbicides.

\footnotetext{
a Presented at a symposium on Absorption and translocation of pesticides by plants on 30 April 1981, organised by the Physicochemical and Biophysical Panel of the Pesticides Group, Society of Chemical Industry.
}

$$
0031-613 X / 82 / 1000-0495 \$ 02.00 \text { C } 1982 \text { Society of Chemical Industry }
$$




\section{Experimental methods}

\subsection{Synthesis of ${ }^{14} \mathrm{C}$-labelled chemicals}

The chemicals used in the tests are given in Table 1.

2.1.1. Preparation of $\left[{ }^{14} \mathrm{C}\right]-O$-methylcarbamoyloximes

The $\left.{ }^{14} \mathrm{C}\right]-O$-methylcarbamoyloximes were prepared from the appropriate oximes using the procequre of Bartley et al. ${ }^{7}$ The oximes $(1 \mathrm{mmol})$ were dissolved in a dry solvent $(5.0 \mathrm{ml})$, either

Table 1. Root Concentration Factors (RCF) and Transpiration Stream Concentration Factors (TSCF) for the uptake of $O$-methylcarbamoyloximes and substituted phenylureas by barley from nutrient solutions

\begin{tabular}{|c|c|c|c|c|c|c|c|c|}
\hline Compound & $\log K_{\text {ow }}^{a}$ & $\begin{array}{c}k^{b} \\
\text { (per day) }\end{array}$ & $\begin{array}{l}\text { Time } \\
\text { (h) }\end{array}$ & $\mathrm{TSCF}_{\mathrm{t}}$ & $\mathrm{TSCF}_{0} \mathrm{c}$ & $\begin{array}{l}\text { Mean } \\
\text { TSCF }_{0}\end{array}$ & $\mathrm{RCF}$ & $\begin{array}{l}\text { Mean } \\
\text { RCF }\end{array}$ \\
\hline \multicolumn{9}{|l|}{$O$-Methylcarbamoyloximes } \\
\hline Aldoxycarb & -0.57 & - & $\begin{array}{l}24 \\
48\end{array}$ & & $\left.\begin{array}{l}0.20 \\
0.18\end{array}\right\}$ & 0.19 & $\left.\begin{array}{l}0.67 \\
0.65\end{array}\right\}$ & 0.66 \\
\hline Oxamyl & -0.47 & 0.39 & $\begin{array}{l}24 \\
48\end{array}$ & $\begin{array}{l}0.16 \\
0.15\end{array}$ & $\left.\begin{array}{l}0.20 \\
0.22\end{array}\right\}$ & 0.21 & $\left.\begin{array}{l}0.75 \\
1.07\end{array}\right\}$ & 0.91 \\
\hline Acetone $O$-methylcarbamoyloxime & -0.13 & - & $\begin{array}{l}24 \\
48\end{array}$ & & $\left.\begin{array}{l}0.28 \\
0.27\end{array}\right\}$ & 0.28 & $\left.\begin{array}{l}0.95 \\
0.95\end{array}\right\}$ & 0.95 \\
\hline Aldicarb & 1.08 & - & $\begin{array}{l}24 \\
48\end{array}$ & & $\left.\begin{array}{l}0.55 \\
0.53\end{array}\right\}$ & 0.54 & $\left.\begin{array}{l}0.98 \\
0.90\end{array}\right\}$ & 0.94 \\
\hline $\begin{array}{l}\text { Benzaldehyde } \\
O \text {-methylcarbamoyloxime }\end{array}$ & 1.49 & 0,48 & $\begin{array}{l}24 \\
48\end{array}$ & $\begin{array}{l}0.50 \\
0.46\end{array}$ & $\left.\begin{array}{l}0.63 \\
0.71\end{array}\right\}$ & 0.67 & $\left.\begin{array}{l}1.47 \\
1.48\end{array}\right\}$ & 1.48 \\
\hline $\begin{array}{l}\text { 4-Chlorobenzaldehyde } \\
O \text {-methylcarbamoyloxime }\end{array}$ & 2.27 & 0.36 & $\begin{array}{l}24 \\
48\end{array}$ & $\begin{array}{l}0.79 \\
0.67\end{array}$ & $\left.\begin{array}{l}0.94 \\
0.94\end{array}\right\}$ & 0.94 & $\left.\begin{array}{l}2.99 \\
2.61\end{array}\right\}$ & 2.80 \\
\hline $\begin{array}{l}\text { 3,4-Dichlorobenzaldehyde } \\
\text { O-methylcarbamoyloxime }\end{array}$ & 2.89 & 0.39 & $\begin{array}{l}24 \\
48\end{array}$ & $\begin{array}{l}0.45 \\
0.33\end{array}$ & $\left.\begin{array}{l}0.54 \\
0.48\end{array}\right\}$ & 0.51 & $\begin{array}{l}5.89 \\
5.32\end{array}$ & 5.61 \\
\hline $\begin{array}{l}\text { 3-Phenoxybenzaldehyde } \\
\text { O-methylcarbamoyloxime }\end{array}$ & 3.12 & 0.28 & $\begin{array}{l}24 \\
48\end{array}$ & $\begin{array}{l}0.21 \\
0.22\end{array}$ & $\left.\begin{array}{l}0.24 \\
0.29\end{array}\right\}$ & 0.26 & $\left.\begin{array}{l}8.82 \\
8.62\end{array}\right\}$ & 8.72 \\
\hline $\begin{array}{l}\text { 3-(3,4-Dichlorophenoxy)benzaldehyde } \\
O \text {-methylcarbamoyloxime }\end{array}$ & 4.6 & * & $\begin{array}{l}24 \\
48\end{array}$ & & $\left.\begin{array}{l}0.08 \\
0.03\end{array}\right\}$ & 0.06 & $\left.\begin{array}{l}85.8 \\
76.4\end{array}\right\}$ & 81.1 \\
\hline \multicolumn{9}{|l|}{ Substituted phenylureas } \\
\hline 3-Methylphenylurea & -0.12 & - & $\begin{array}{l}24 \\
48\end{array}$ & & $\left.\begin{array}{l}0.048 \\
0.054\end{array}\right\}$ & 0.051 & $\left.\begin{array}{l}0.69 \\
0.77\end{array}\right\}$ & 0.73 \\
\hline Phenylurea (unsubstituted) & 0.80 & - & $\begin{array}{l}24 \\
48\end{array}$ & & $\left.\begin{array}{l}0.48 \\
0.46\end{array}\right\}$ & 0.47 & $\left.\begin{array}{l}1.20 \\
1.20\end{array}\right\}$ & 1.20 \\
\hline 4-Fluorophenylurea & 1.04 & - & $\begin{array}{l}24 \\
48\end{array}$ & & $\left.\begin{array}{l}0.48 \\
0.45\end{array}\right\}$ & 0.47 & $\left.\begin{array}{l}1.09 \\
1.10\end{array}\right\}$ & 1.10 \\
\hline 3-(Methylthio) phenylurea & 1.57 & 一 & $\begin{array}{l}24 \\
48\end{array}$ & & $\left.\begin{array}{l}0.27 \\
0.16\end{array}\right\}$ & 0.22 & $\left.\begin{array}{l}0.89 \\
0.98\end{array}\right\}$ & 0.94 \\
\hline 4-Chlorophenylurea & 1.80 & - & $\begin{array}{l}24 \\
48\end{array}$ & & $\left.\begin{array}{l}0.52 \\
0.48\end{array}\right\}$ & 0.50 & $\left.\begin{array}{l}2.00 \\
2.00\end{array}\right\}$ & 2.00 \\
\hline 4-Bromophenylurea & 1.98 & - & $\begin{array}{l}24 \\
48\end{array}$ & & $\left.\begin{array}{l}0.55 \\
0.54\end{array}\right\}$ & 0.55 & $\left.\begin{array}{l}3.04 \\
3.30\end{array}\right\}$ & 3.17 \\
\hline 3,4-Dichlorophenylurea & 2.64 & - & $\begin{array}{l}24 \\
48\end{array}$ & & $\left.\begin{array}{l}0.39 \\
0.35\end{array}\right\}$ & 0.37 & $\left.\begin{array}{l}5.50 \\
6.22\end{array}\right\}$ & 5.86 \\
\hline 4-Phenoxyphenylurea & 2.80 & 0.69 & $\begin{array}{l}24 \\
48\end{array}$ & $\begin{array}{l}0.34 \\
0.25\end{array}$ & $\left.\begin{array}{l}0.47 \\
0.46\end{array}\right\}$ & 0.47 & $\left.\begin{array}{l}6.54 \\
7.61\end{array}\right\}$ & 7.08 \\
\hline 4-(4-Bromophenoxy)phenylurea & 3.7 & - & $\begin{array}{l}24 \\
48\end{array}$ & & $\left.\begin{array}{l}0.10 \\
0.11\end{array}\right\}$ & 0.11 & $\left.\begin{array}{l}35.2 \\
34.5\end{array}\right\}$ & 34.9 \\
\hline
\end{tabular}

\footnotetext{
${ }^{a}$ Octan-1-ol/water partition coefficients $\left(K_{\mathbf{o w}}\right)$.
}

${ }^{b}$ Rate coefficient for the degradation of chemical in the plant shoots; missing values indicate that the degradation was immeasurably slow over the time scale of the tests.

- The values of TSCF 0 given are either the measured values of the TSCF of compounds, the degradation of which was immeasurably slow, or the measured values $\left(\mathrm{TSCF}_{\mathrm{t}}\right)$, corrected for degradation.

* Degradation could not be measured, as uptake was so small. 
hexane, or 1,4-dioxane [3,4-dichlorobenzaldehydeoxime and the oxime precursors of oxamyl and aldoxycarb (aldicarb sulphone)], or benzene (other substituted benzaldehyde oximes), and treated with $\left[{ }^{14} \mathrm{C}\right]$ methylisocyanate, generated from $\left[{ }^{14} \mathrm{C}\right]$ methylammonium chloride and $1,1^{\prime}-$ carbonyldi-imidazole. Anhydrous conditions are essential; the hydrocarbon solvents were redistilled over sodium and the 1,4-dioxane over calcium hydride.

After the reaction mixture had stood overnight, the products were purified by preparative thin-layer chromatography (t.l.c.) on silica gel $G F_{254}$. The solvents were hexane +acetone $(2+1$ by volume) or, for oxamyl, aldoxycarb and acetone $O$-methylcarbamoyloxime, diethyl ether + acetone $(4+1$ by volume), and the desired compounds were finally eluted from the silica with acetone. Yields were between 35 and $75 \%$. All the products had a radiochemical purity of at least $98 \%$ as assessed by t.l.c., and specific activities of about $0.25 \mathrm{mCi} \mathrm{mmol}^{-1}$.

\subsubsection{Preparation of the $\left[{ }^{14} \mathrm{C}\right]$ phenylureas}

The appropriate substituted aniline $(1 \mathrm{mmol})$ was dissolved in aqueous acetic acid, and an aqueous solution of potassium $\left[{ }^{14} \mathrm{C}\right]$ cyanate $(1 \mathrm{mmol})$ was added. The solution was warmed to $40^{\circ} \mathrm{C}$ for $30 \mathrm{~min}$, and the precipitate of phenylurea was filtered and purified by column chromatography on silica gel with hexane + acetone as eluent. Yields were at least $80 \%$. The 3-(methylsulphonyl)phenylurea (not readily synthesised from the aniline) was prepared by oxidising 3-(methylthio)phenylurea with peracetic acid and separated from traces of the sulphoxide by column chromatography on silica gel using hexane + acetone as eluent. Radiochemical purities were at least $95 \%$ assessed by t.l.c., and specific activities were about $0.2 \mathrm{mCi} \mathrm{mmol}^{-1}$.

\subsection{Growth and treatment of barley plants}

\subsubsection{Uptake of chemical}

Seeds of barley (Hordeum vulgare cv. Georgie), germinated on moist tissue paper, were transferred to aerated nutrient solution (half-strength Hoaglands), ${ }^{8}$ and grown in a controlled environment with a 16-h day (light intensity $10 \mathrm{klx}$ ) at $20^{\circ} \mathrm{C}$ and 8 -h night at $16^{\circ} \mathrm{C}$; humidity was not controlled.

To measure the uptake of chemicals, 10-day-old plants were transferred to nutrient solution containing the chemical under test. Groups of six plants were grown in each vessel, the plants being individually held in drilled rubber bungs fitted into holes in an aluminium plate resting flush on a $6.5 \mathrm{~cm}$-diam. glass crystallising dish with darkened sides. This dish contained the solution $(100 \mathrm{ml})$ of ${ }^{14} \mathrm{C}$-labelled chemical at an initial concentration of $5 \mu \mathrm{M}$ [except for 3-(3,4-dichlorophenoxy)benzaldehyde $O$-methylcarbamoyloxime which was soluble only to $1 \mu \mathrm{M}$; this compound was strongly absorbed by the roots so that the solution was rapidly depleted, and therefore after $1 \mathrm{~h}$, the plants were transferred to a fresh solution of chemical at the original concentration]. Transpiration, corrected for evaporation using an identical vessel without plants, was measured by weighing the vessel and plants at the beginning and end of each test, when the concentration of the chemical remaining in solution was also measured (duplicate $1.0-\mathrm{ml}$ aliquots). At the end of the uptake period ( 24 or $48 \mathrm{~h}$ ), shoots from all the plants in one vessel were cut off and combined, and the roots blotted dry, combined and weighed. Plant samples were stored at $-16^{\circ} \mathrm{C}$ until they could be analysed. Typical root weights were $0.1 \mathrm{~g}$ per plant, and transpiration $1.0 \mathrm{ml}$ per plant per day; none of the chemicals affected the transpiration rate.

\subsubsection{Degradation of chemicals}

The rate of degradation of the chemicals in the shoots was measured using groups of three plants grown in a solution $(40 \mathrm{ml})$ of the chemical under test held in glass vials under the conditions described above. After $24 \mathrm{~h}$, the transpiration was measured, and then the plants were transferred to nutrient solution $(40 \mathrm{ml})$ without chemical; after $1 \mathrm{~h}$, to permit most of the chemical in or on the roots to be desorbed, they were transferred again to fresh nutrient solution $(40 \mathrm{ml})$. The combined shoots of all three plants from one vessel were taken for analysis after 24, 48, 72 or $96 \mathrm{~h}$.

\subsection{Measurement of chemicals}

Root or shoot samples from each treatment were macerated with acetone ( 5 to $10-\mathrm{ml}$ portions) 
in a glass mortar and pestle, and the extracts were filtered through cotton wool into volumetric flasks $(100 \mathrm{ml}$ for six roots or shoots, $50 \mathrm{ml}$ for three). Extraction was continued until no colour remained in the tissues; the flask contents were then made up to volume. Duplicate aliquots $(20 \mathrm{ml})$ of the extract were rotary evaporated to dryness at a bath temperature not exceeding $40^{\circ} \mathrm{C}$, and the residues transferred in a little acetone to a $2.5-\mathrm{cm}$-wide band on a silica gel $\mathrm{GF}_{254}$ t.l.c. plate. Unlabelled compounds were used as markers. The plates were developed in diethyl ether (substituted benzaldehyde $O$-methylcarbamoyloximes) or diethyl ether + acetone ( $4+1$ by volume) (phenylureas and the aliphatic $O$-methylcarbamoyloximes). Bands of silica gel containing the parent compound, and those containing the oxidative metabolites of the thioether compounds, were observed under an ultraviolet lamp and scraped into aliquots of a scintillation cocktail for radioactivity counting. ${ }^{9}$

The efficiency of this extraction procedure was assessed by adding known amounts of the ${ }^{14} \mathrm{C}$ labelled compounds to untreated plant tissues, and was generally better than $85 \%$. The recovery of acetone $O$-methylcarbamoyloxime was only $79 \%$, probably due to losses by volatilisation during solvent removal. All the results were corrected for the appropriate efficiency of recovery. A small and variable amount of oxidation of the thiether compounds to the corresponding sulphinyls occurred during the extraction and t.l.c., but no correction was made for this.

\subsection{Calculation of results}

The Root Concentration Factors were calculated from

$$
\begin{aligned}
\mathrm{RCF}= & {[\text { Radioactivity }(\text { d.p.m. }) \text { in roots } \times 100] /[\text { wt of roots }(\mathrm{g})} \\
& \left.\times \text { radioactivity }\left(\text { d.p.m. } \mathrm{ml}^{-1}\right) \text { of final solution } \times \text { recovery }(\%)\right]
\end{aligned}
$$

It was assumed that the establishment of equilibrium between the chemical in the roots and in the external solution was sufficiently rapid that the effects of degradation in the root on RCF were negligible.

The Transpiration Stream Concentration Factors were calculated from

$$
\begin{array}{r}
\mathrm{TSCF}=[\text { Radioactivity }(\text { d.p.m. }) \text { in shoots } \times 100] / \text { [wt of water transpired }(\mathrm{g}) \\
\left.\times \text { radioactivity }\left(\text { d.p.m. } \mathrm{ml}^{-1}\right) \text { of solution } \times \text { recovery }(\%)\right]
\end{array}
$$

As transpiration is continuous, the mean of the initial and final concentrations was used in this calculation of TSCF.

The TSCF measured in this way will be lower than the true TSCF if the chemical is being degraded in the shoots. The value corrected for degradation $\left(\mathrm{TSCF}_{0}\right)$ was calculated from the experimental values $\left(\mathrm{TSCF}_{\mathrm{t}}\right)$ measured at time $t$, using the estimate of the degradation rate $(k)$ of the chemical in the shoots given in Table 1 and assuming a constant rate of uptake and degradation

$$
\operatorname{TSCF}_{0}=\left(\operatorname{TSCF}_{\mathrm{t}} \cdot t \cdot k\right) /[1-\exp (k t)]
$$

The degradation rate was estimated by first accumulating chemical in the shoots over a $24-\mathrm{h}$ uptake period and then monitoring the subsequent decline over $96 \mathrm{~h}$ following the transfer to untreated nutrient solution. The amount of chemical initially present following the 24-h uptake period was calculated using the 24-h TSCF obtained above, together with the solution concentrations and the volume of water transpired. From the amounts of chemical measured in the shoots over the degradation period, the logarithm of the percentage of chemical remaining was plotted against time to obtain the first-order decay constant. The washed roots of the transferred plants were assumed to contain negligible amounts of chemical for subsequent translocation (see Discussion).

The assumptions of a constant degradation rate in the shoots and a constant rate of chemical uptake are not strictly correct due to the differing day and night regimes. However, the error introduced is not likely to be large because the correction to the TSCF for degradation was usually small. Degradation of the chemicals in the nutrient solution was shown by t.l.c. tests to be negligible over the period of the experiments. 
The methylthio compounds, aldicarb and 3-(methylthio)phenylurea, were found in the shoots largely as the sulphinyl and, to a lesser extent, the sulphonyl compounds, It was assumed that the parent methylthio compounds were translocated, and that oxidation occurred subsequently in the leaves. Thus the TSCF was calculated from the total of the parent thioether and the two oxidative metabolites found in the shoots.

\subsection{Octan-1-ol/water partition coefficients ( $K_{\mathrm{ow}}$ )}

These were obtained by standard procedures ${ }^{10}$ with measurements by liquid scintillation counting or, for the more lipophilic benzaldehyde $O$-methylcarbamoyloximes, by reverse-phase high-pressure liquid chromatography on octadecyl silica with methanol/water mixtures as eluents. The value for 3-(3,4-dichlorophenoxy)benzaldehyde $O$-methylcarbamoyloxime was estimated from Hansch relationships. ${ }^{11}$ Values of $K_{\text {ow }}$ are given in Table 1.

\subsection{Partition of chemicals between macerated roots and water}

Roots from 10-day-old barley plants were blotted dry, and frozen in liquid nitrogen to destroy the cell structure. The frozen roots were crushed to a powder with a glass rod. Duplicate samples $(0.2 \mathrm{~g})$ were freeze-dried in 30-ml glass centrifuge tubes, and the root solids shaken for $2 \mathrm{~h}$ with a $5 \mu \mathrm{M}$-solution ( 2.5 or $10.0 \mathrm{ml})$ of the ${ }^{14} \mathrm{C}$-compound [1 $\mu \mathrm{M}$ for 3-(3,4-dichlorophenoxy)benzaldehyde $O$-methylcarbamoyloxime, see section 2.2.1] in water. The amount of chemical absorbed by the roots was calculated from the change in the solution concentration, measured by liquid scintillation counting of duplicate aliquots $(0.5$ or $1.0 \mathrm{ml})$. The partition coefficients of the chemicals between macerated roots and water were calculated on the basis of fresh root weights.

\section{Results and discussion}

\subsection{Root uptake of chemicals}

The uptake of the chemicals into barley roots is given in Table 1. The RCF values measured for the parent compounds alone, or for the parent compounds plus the oxidative metabolites for the methylthio compounds, were very similar after 24 and $48 \mathrm{~h}$, indicating that root uptake rapidly reached an equilibrium value. Repeated measurements agreed within $\pm 5 \%$. The values increased with increasing lipophilicity (assessed by the octan-1-ol/water partition coefficients) and decreased to a limiting value of less than unity for polar compounds.

The sorption of chemicals by macerated roots (Figure 1) was close to the RCF values for the more lipophilic chemicals, but, in contrast to the RCF (Figure 2), continued to fall sharply as the

Figure 1. Relationship between the absorption of chemicals by macerated barley roots (expressed as the Root Concentration Factor), and their octan-1-ol/water partition coefficients (as log $\left.K_{0 w}\right): O$, substituted benzaldehyde $O$-methylcarbamoyloximes; and $x$, substituted phenylureas.

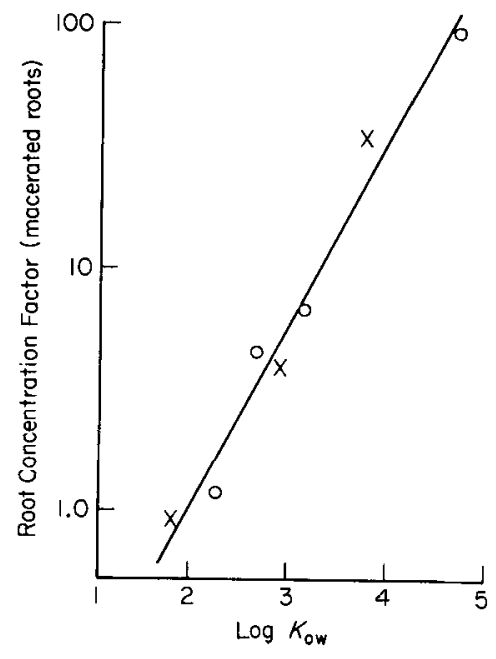




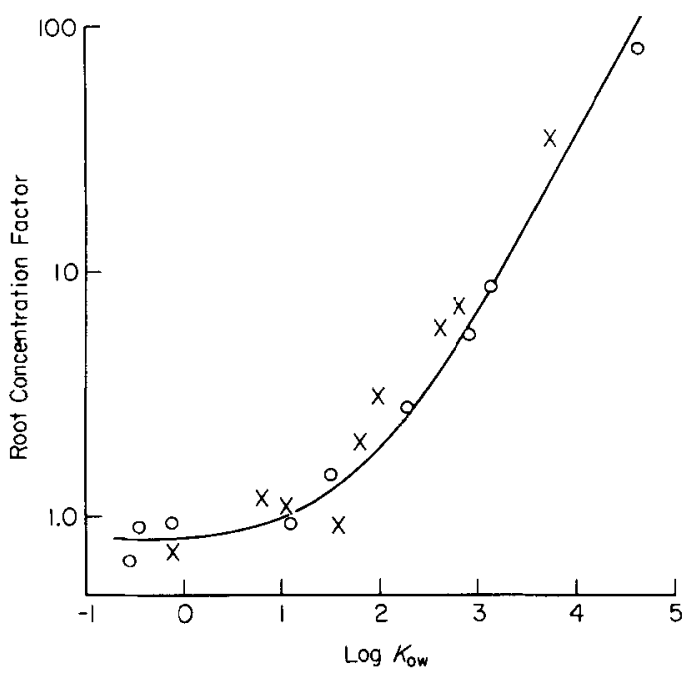

Figure 2. Relationship between the uptake of chemicals by barley roots (expressed as the Root Concentration Factor), and their octan-1-ol/water partition coefficients (as log $\left.K_{\text {ow }}\right): \quad O, O$-methylcarbamoyloximes; and $\times$, substituted phenylureas.

lipophilicity decreased, the sorption of benzaldehyde $O$-methylcarbamoyloxime itself and more polar $O$-methylcarbamoyloximes being too weak to be measured. There was a linear relationship between $\log \mathrm{RCF}$ (macerated roots) and $\log \mathrm{K}_{\mathrm{ow}}$, and the following regression line was fitted:

$n=7 ; \quad r=0.981$.

$\log$ RCF (macerated roots) $=0.77 \log K_{\mathrm{ow}}-1.52$

The sorption of chemicals by macerated roots is thus seen as a partitioning to the lipophilic constituents of root solids, and equation (1) is an example of the linear free-energy relationships derived by Collander ${ }^{12}$ for the partitioning of chemicals between different pairs of immiscible solvents.

The close correspondence between sorption by the macerated roots and uptake of the more lipophilic chemicals into the roots of intact plants suggests that this partition process accounts for most of the observed RCF for these compounds. The rapid accumulation of chemicals in the root up to an equilibrium concentration that does not change further with time, as also observed in other studies, ${ }^{6,13,14}$ and the reversibility of the uptake process on transfer to a solution not containing chemical, ${ }^{3}$ can be explained simply as a partition process.

However, for the polar compounds, for which partition on to macerated roots was either weak or not measurable, the RCF values fell to a limiting value of $0.6-1.0$. This may be explained by invoking a second mechanism of uptake which, although it may occur to the same extent for all compounds, constitutes a major proportion of the RCF only for the polar compounds. To estimate this contribution, the amount of chemical partitioned to the root solids was calculated from equation (1) for each of the nine polar compounds having an RCF value $<2$, and subtracted from the measured $R C F$, to yield a value of $0.82( \pm 0.20)$ as the limiting RCF for polar compounds.

Assuming that the RCF can be explained by these two processes (a partitioning to lipophilic root solids described by equation (1), and a small uptake taken to be constant for all compounds), the following relationship between RCF and $\log K_{\text {ow }}$ was obtained:

$$
\log (\mathrm{RCF}-0.82)=0.77 \log K_{\mathrm{ow}}-1.52
$$

This line fits well the measured data for the $O$-methylcarbamoyloximes and phenylureas (Figure 2). The mechanism of the small uptake contributing 0.82 to the RCF value can be ascribed most simply to equilibration of the chemical between the external solution and the water contained within the roots, both within the free space and the cells. If such equilibration were complete, a contribution of about 0.9 to the RCF value would be expected for roots containing $90 \%$ water by weight, so that the measured value of 0.82 suggests that equilibration was nearly complete. However, 
it is possible that a small volume of the root, for example the cells lying within the Casparian strip of the endodermis, does not fully equilibrate with the external solution.

Whether the more lipophilic chemicals behave similarly, as was assumed in equation (2), is conjectural, as the large contribution to the RCF of the partitioning of such chemicals to the root solids masks any other uptake mechanisms. Crowdy et al. ${ }^{14}$ have postulated that the uptake of griseofulvin by roots is also due to sorption on the lipophilic constituents of root solids. Tames and Hance $^{15}$ showed that triazine and phenylurea herbicides were taken up by roots of several plant species killed by boiling; this provides further evidence that the uptake by roots of rather lipophilic chemicals is dominated by physical sorption. Hartley and Graham-Bryce ${ }^{16}$ have recently reviewed this topic, but unfortunately much of the literature on the uptake of chemicals by roots lacks some of the information necessary to calculate RCF values for comparison with the present work. However, the uptake of the same series of phenylureas as used in this study by maize, beans and wheat (Briggs, G. G., unpublished) fits equation (2) reasonably well, as do data taken from the literature for other plants and chemicals (Figure 3). Thus the proposed mechanism for the uptake of chemicals from solution by roots may be of general application for non-ionised chemicals, and for plants with non-woody roots. This suggests that the lipophilic nature of root solids does not vary widely amongst the plant species studied.

Figure 3. Relationship between the literature values of the Root Concentration Factors, and the octan-1-ol/water partition coefficients (as $\left.\log K_{\text {ow }}\right): \times$, oryzalin by maize $;^{18}$ O, diphenamid by tomato $;^{19}$, herbicides by soya bean $;^{20}$ $\triangle$, pyroxychlor by tomato; $;^{21} \Delta$, lindane by coffee; $\square$, fungicides by maize; ${ }^{5} \square$, propaphos by rice; ${ }^{22}$ and + , triazines by barley. ${ }^{6}$ Curve as in Figure 2.

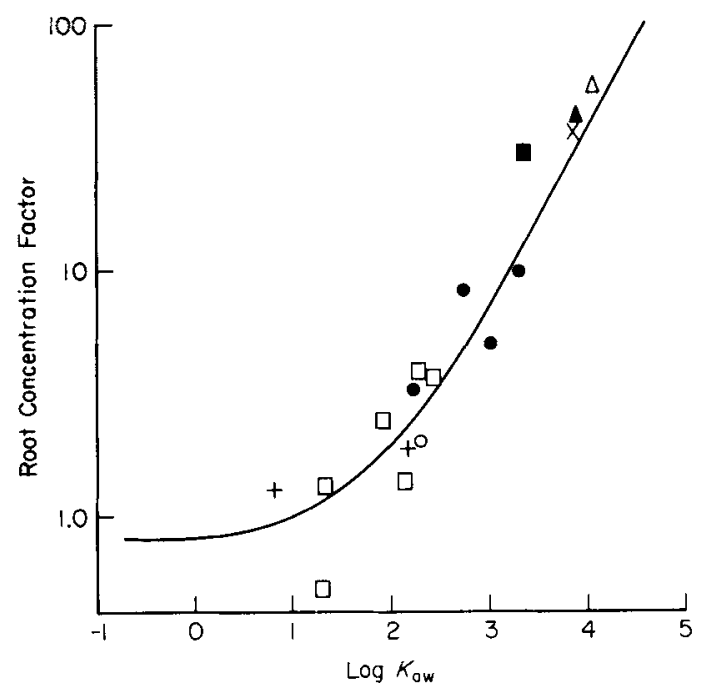

\subsection{Uptake into shoots}

The TSCF values for the 18 chemicals in barley are given in Table 1. For each chemical, the values measured after 24 and $48 \mathrm{~h}$ were similar, and were identical within experimental error when the correction for degradation was applied. Many of the measurements were repeated several times, and the typical variability between different tests for the TSCF values was about $\pm 10 \%$. All the TSCF values are less than unity, indicating that the chemicals move passively into the shoot with the transpiration water and are not taken up against a concentration gradient.

Both series of chemicals behaved similarly. There is an optimum lipophilicity for maximum translocation to shoots (Figure 4), centred at $\log K_{\text {ow }}=1.8$. More polar compounds were taken up less well, with a TSCF of about 0.2 for the very polar compounds aldoxycarb and oxamyl, whilst the uptake of very lipophilic compounds with $\log K_{\text {ow }}>4.5$ was very small (care must be taken in the tests to ensure that the solutions of very lipophilic chemicals do not contact the base of the shoots, for such chemicals are rapidly sorbed by plant tissues, and this would give rise to spuriously high 


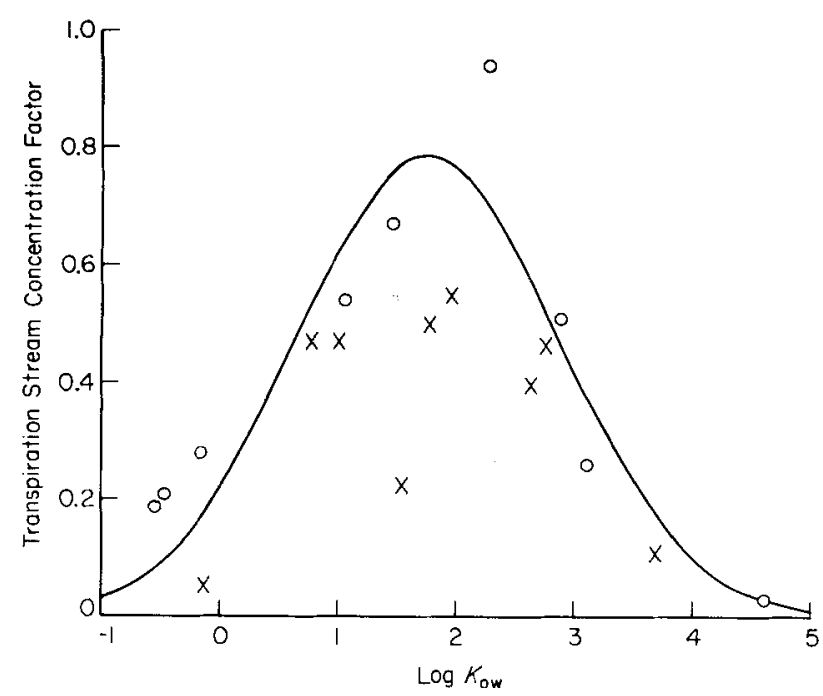

Figure 4. Relationship between the translocation of chemicals to barley shoots following uptake by the roots (expressed as the Transpiration Stream Concentration Factor), and the octan-1-ol/water partition coefficients (as $\log K_{\text {ow }}$ ): $O, O$-methylcarbamoyloximes; and $x$, substituted phenylureas.

values of the TSCF). A Gaussian curve has been fitted to the data for illustrative purposes (Figure 4), and the equation for 17 compounds (excluding 3-(methylthio)phenylurea) is:

$$
\mathrm{TSCF}=0.784 \exp -\left[\left(\log K_{\mathrm{ow}}-1.78\right)^{2} / 2.44\right]
$$

The TSCF value of 0.22 for 3-(methylthio)phenylurea was much less than expected from its $\log K_{\text {ow }}$ of 1.57 . It is possible that this compound is readily oxidised in the root, so that the measured TSCF may reflect, at least in part, the TSCF for the sulphinyl derivative (the sulphoxide), which having a $\log K_{\text {ow }}$ estimated as -0.2 would be expected to be poorly translocated. However, the TSCF for aldicarb, the other methylthio compound studied, was not anomalously low, although it was also recovered from the shoots, largely as the sulphinyl derivative.

It has been suggested previously that there is an optimum lipophilicity for translocation. ${ }^{1,4}$ Most pesticides described as having systemic activity, that is, insecticides, fungicides and soilapplied herbicides which act by inhibiting photosynthesis in the leaf, have octan-1-ol/water partition coefficients in the range $\log K_{\text {ow }}=-0.5$ to 3.5 . Where literature data could be used to obtain TSCF values, they fitted the bell-shaped curve established in the present study reasonably well (Figure 5) despite the wide ranges of chemical structures and plant species involved. Only carrot and parsnip, two species which develop swollen storage roots from an early stage of growth, failed to translocate chemicals ${ }^{13}$ as well as expected; this may be due to different root physiology or to increased metabolism of the chemicals before they reach the xylem tissues. Rapid metabolism of chemicals in plant roots can markedly reduce translocation; for example, simazine is well tolerated by maize when applied via the roots, due to rapid hydroxylation of the triazine ring in the root tissue, but it is phytotoxic when detached leaves are grown in solutions containing the same concentration of the chemical.

The factors affecting the translocation of chemicals from roots to shoots are poorly understood. Polar chemicals may pass through the lipid membranes in the root with difficulty, whereas the passage of water is presumably not hindered, resulting in selective rejection of these chemicals at the membrane barriers. Lipophilic molecules on the other hand, being reversibly sorbed by the root solids, might be expected to pass to the xylem unhindered once equilibrium is reached, resulting in a TSCF of unity. ${ }^{16}$ However, very lipophilic molecules are not readily transported in plants even after long exposure to the chemical; for instance, $\gamma$-hexachlorocyclohexane in coffee. ${ }^{1 ?}$ Furthermore, in the reported tests, a 'steady state' was soon reached as the RCF and TSCF values did not change between 24 and $48 \mathrm{~h}$. Thus the low TSCF values for the lipophilic compounds cannot be explained by the roots continually removing chemical from the transpiration stream 
Figure 5. Relationship between the literature values of Transpiration Stream Concentration Factors and the octan-1-ol/water partition coefficients (as $\log K_{\text {ow }}$ ): $\mathbf{\square}$, herbicides by barley; ${ }^{6} \square$, homologues of the fungicide isoprothiolane (di-isopropyl 1,3-dithiolan-2-ylidenemalonate) by rice; ${ }^{23} \bullet$, atrazine and linuron by lettuce and turnip;13 $O$, atrazine and linuron by carrot and parsnip; $;^{13}$ and $\Delta$, atrazine by wheat. ${ }^{24}$ Curve as in Figure 4.

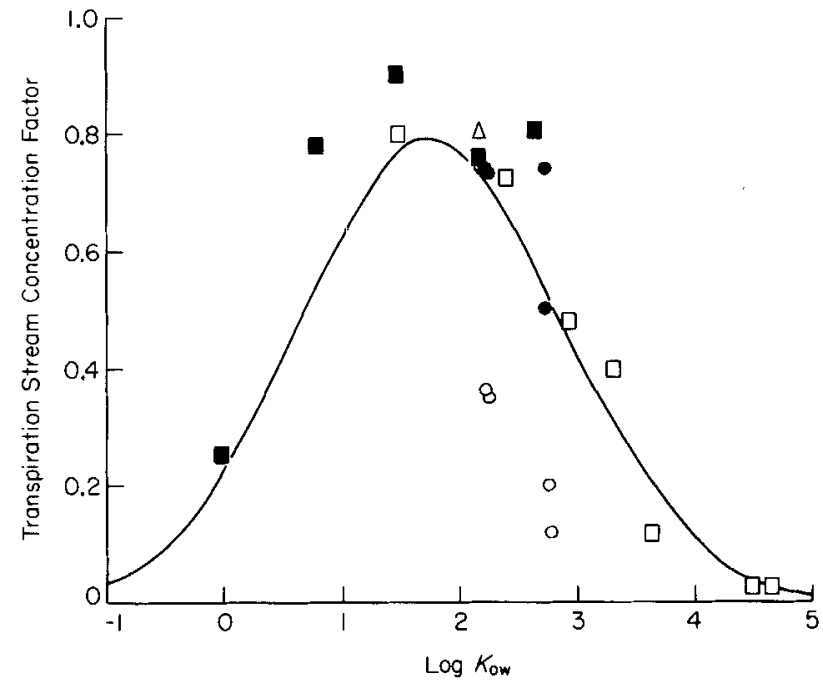

by absorption, as this would have resulted in a substantial increase in the RCF between 24 and $48 \mathrm{~h}$. Clearly these results bear out the statement of Hartley and Graham-Bryce ${ }^{16}$ that it is almost certainly a gross over-simplification to suggest that the TSCF is influenced only by reversible partition into the non-aqueous phases in the root.

Whether the measured uptake of chemicals by the roots has any bearing on translocation to shoots is open to question. Crowdy et al. ${ }^{14}$ observed that plants grown in griseofulvin solution, and then transferred to solutions without the chemical, continued to accumulate griseofulvin in the shoots. This was taken to signify that the roots were providing a reservoir of the chemical for subsequent translocation. In the present study, further uptake of lipophilic chemicals was also observed when plants were transferred to fresh solution without the chemical. However, measurements of the chemical in this fresh solution showed that the chemical in the roots was re-equilibrated with the external solution to the same RCF as previously. The observed further accumulation in the shoots agreed closely with that calculated from the new solution concentration, the TSCF and the volume of water transpired. Thus the roots do not provide a reservoir of chemical that can be directly translocated to the shoots. Washing the roots as in these degradation tests removed much of the chemical remaining in the roots, so that further uptake to the shoots was not then observed.

A possible relationship between the RCF and the TSCF was observed by Shone et al ${ }^{3}$ who, by analysing the kinetics of uptake and elution of chemicals from roots, showed that the RCF could be divided into three components. The contribution of the compartment that filled and emptied most rapidly (the 'rapidly diffusible fraction') to the RCF appeared to correlate with the TSCF. However, if the TSCF were controlled by the filling of a root compartment, then one might well expect this compartment to be relatively inaccessible to the chemical, especially for the compounds of low TSCF. It is possible that this observed agreement is fortuitous, and reflects more an increase in lipophilicity along the relatively polar series of chemicals studied, resulting in an increasing RCF component due to lipid adsorption, and in TSCF values that increased as the optimal lipophilicity for translocation was approached but only slightly exceeded.

\section{Conclusions}

The accumulation of non-ionised chemicals by roots is ascribed to two processes: partitioning of chemicals to lipophilic root solids, and uptake into the aqueous phase in roots contained in the free space and within the root cells. The partitioning process dominates for lipophilic chemicals, giving rise to large RCF values. Although the second process, uptake by the aqueous phase in the root, 
may occur for all chemicals it could be clearly demonstrated only for polar compounds, which partition weakly to root solids, and here contributed about 0.82 to the RCF values.

Translocation of the $O$-methylcarbamoyloximes and substituted phenylureas to the shoots was a passive process with a TSCF value of less than unity, and was maximal for compounds of intermediate polarity having $\log K_{\text {ow }}$ between 1.5 and 2.0 .

Neither the RCF nor the TSCF, when corrected for degradation, changed significantly between 24 and $48 \mathrm{~h}$ after the start of treatment with the chemicals, indicating that the measured values of these parameters are equilibrium values that are probably maintained over longer periods. No relationships between the uptake by the root and the subsequent translocation to the shoot could be discerned; the selective rejection of the more polar and more lipophilic compounds from the transpiration stream, presumably occurring at membrane barriers in the root, could not be satisfactorily explained in terms of a series of simple partitions within the root.

\section{Acknowledgements}

The authors thank Mr R. Edmondson, Miss M. Johnston and Mrs M. Thompson for preliminary work on this project, Mr G. J. Smith for the scintillation counting, and Miss G. L. Smith for the statistical analysis.

\section{References}

1. Crowdy, S. H. Proc. Br. Insectic. Fungic. Conf., 7th 1973, 831-839.

2. Shone, M. G. T.; Wood, A. V. Proc. Br. Insectic. Fungic. Conf., 7th 1973, 151-159.

3. Shone, M. G. T.; Bartlett, B. O.; Wood, A. V. J. exp. Bot. 1974, 25, 401-409.

4. Briggs, G. G.; Bromilow, R. H.; Edmondson, R.; Johnston, M. Chem. Soc. Spec. Publ. No. 29 1976, pp. 129-134.

5. Leroux, P.; Gredt, M. Neth. J. Plant Pathol. 1977, 83, (Suppl. 1), 51-61.

6. Shone, M. G. T.; Wood, A. V. J. exp. Bot. 1974, 25, 390-400.

7. Bartley, W. J.; Heywood, D. L.; Steele, T. E. N.; Skraba, W. J. J. Agric. Food Chem. 1966, 14, $604-607$.

8. Hoagland, D. R.; Arnon, D. J. Circ. Calif. Agric. Exp. Stn. 1960, 347.

9. Bromilow, R. H.; Baker, R. J.; Freeman, M. A. H.; Görög, K. Pestic. Sci. 1980, 11, 371-378.

10. Fujita, T.; Iwasa, J.; Hansch, C. J. Am. Chem. Soc. 1964, 86, 5175-5180.

11. Leo, A.; Hansch, C.; Elkins, D. Chem. Rev. 1971, 71, 525-616.

12. Collander, R. Physiol. Plant. 1954, 7, 420-445.

13. Walker, A.; Featherstone, R. M. J. exp. Bot. 1973, 24, 450-458.

14. Crowdy, S. H.; Grove, J. F.; Hemming, H. G.; Robinson, K. C. J. exp. Bot. 1956, 7, 42-64.

15. Tames, R. S.; Hance, R. J. Plant Soil 1969, 30, 221-226.

16. Hartley, G. S.; Graham-Bryce, I. J. Physical Principles of Pesticide Behaviour Vol. 2, Academic Press, London, 1980, pp. 596-611.

17. Rüegg, E. F.; Lord, K. A.; Mesquita, T. B. Arq. Inst. Biol. (Sao Paulo) 1977, 44, 235-246.

18. Upadhyaya, M. K.; Nooden, L. D. Plant Physiol. 1980, 66, 1048-1052.

19. Long, J. W.; Thompson, L.; Rieck, C. E. Weed Sci. 1974, 22, 42-47.

20. Moody, K.; Kust, C. A.; Buchholtz, K. P. Weed Sci. 1970, 18, 642-647.

21. Small, L. W.; Martin, R. A.; Edgington, L. V. Neth. J. Plant Pathol. 1977, 83, (Suppl. 1), 63-70.

22. Fujii, Y.; Asaka, S.; Misato, T. Nippon Noyaku Gakkaishi (J. Pestic. Sci) 1980, 5, 55-62.

23. Uchida, M. Pestic. Biochem. Physiol. 1980, 14, 249-255.

24. Walker, A. Pestic. Sci. 1972, 3, 139-148. 